\title{
Retraction Note: Soft computing methodologies for estimation of bridge girder forces with perforations under tsunami wave loading
}

\author{
Shatirah Akib ${ }^{1}$. Sadia Rahman ${ }^{1}$. Shahaboddin Shamshirband ${ }^{2,3} \cdot$ Dalibor Petković $^{4}$
}

Published online: 31 March 2020

(c) Springer Nature B.V. 2020

\section{Retraction to: Bull Earthquake Eng (2015) 13:935-952 https://doi. org/10.1007/s10518-014-9656-3}

The Editor-in-Chief has retracted this article (Akib et al. 2015) because the validity of the content of this article cannot be verified. This article showed evidence of substantial text overlap [most notably with the articles cited (Akib et al. 2014; Ramedani et al. 2014; Rahman et al. 2014; Zakaria et al. 2014)], peer review and authorship manipulation. Authors Shatirah Akib and Shahaboddin Shamshirband do not agree to this retraction. Authors Sadia Rahman and Dalibor Petković have not responded to correspondence about this retraction.

\section{References}

Akib S, Rahman S, Shamshirband S (2014) J Coast Conserv

Akib S, Rahman S, Shamshirband S et al (2015) Reverse engineering of the Mitkovic type internal fixator for lateral tibial plateau. Bull Earthq Eng 13:935. https://doi.org/10.1007/s10518-014-9656-3

Rahman S, Akib S, Khan MTR, Triatmadja R (2014) Performance of bridge girder with perforations under Tsunami wave loading. Int J Bioeng Life Sci 8(2):139

Ramedani Z, Omid M, Keyhani A et al (2014) Potential of radial basis function based support vector regression for global solar radiation prediction. Renew Sustain Energy Rev 39:1005-1011

Zakaria R, Sheng OY, Wern K et al (2014) Adaptive neuro-fuzzy evaluation of the tapered plastic multimode fiber-based sensor performance with and without silver thin film for different concentrations of calcium hypochlorite. IEEE Sens J 14(10):3579

Publisher's Note Springer Nature remains neutral with regard to jurisdictional claims in published maps and institutional affiliations.

The original article can be found online at https://oi.org/10.1007/s10518-014-9656-3.

Shatirah Akib

shatirah@um.edu.my

1 Department of Civil Engineering, University of Malaya, 50603 Kuala Lumpur, Malaysia

2 Department of Computer System and Technology, Faculty of Computer Science and Information Technology, University of Malaya, 50603 Kuala Lumpur, Malaysia

3 Department of Computer Science, Chalous Branch, Islamic Azad University (IAU), Chalous, Mazandaran 46615-397, Iran

4 Department for Mechatronics and Control, Faculty of Mechanical Engineering, University of Niš, Aleksandra Medvedeva 14, Niš 18000, Serbia 